\title{
The users' tendency to different packaging materials regarding to the type of product
}

\author{
Maja Brozović, Bruno Bucić, Doris Čikara, Antonija Lasić, Dorotea Kovačević, \\ Josip Bota
}

University of Zagreb, Faculty of Graphic Arts, Getaldićeva 2, Zagreb, Croatia

\begin{abstract}
The most important role of packaging is protecting a product, but also stimulating purchasing decision. Products on store shelfs can often be found packaged in different materials, even when they are of the same net weight. This study investigated how different packaging materials affect purchasing decision. The aim was to evaluate the user's tendency towards a particular packaging material in relation to its functionality and environmental protection. Test samples were three common powder products: instant coffee, cocoa and sugar. Respondents' task was to select one of the following packaging materials: glass, tin and composite material for coffee; rigid and flexible plastics for cocoa and sugar. The results showed that the user's tendency towards packaging material is influenced by packaging functionality. In addition, technical (protection, recyclability) and ergonomic (presence of the lid, easy to dose and reusability) attributes have found to be essential criteria for the choice of packaging. Furthermore, this study showed that customers are ecologically aware since they tend to re-use the packaging, thus enhancing environmental care.
\end{abstract}

Key words: users' preferences, packaging material, protection, recyclability, reusability

\section{Introduction}

The packaging is a sheath that covers the product, and is intended to protect the product during storage, sale and use. Previous studies showed that product protection (which may be consumer protection in the same time) is a key function of the packaging. Problems associated with insufficient protection lead to customer's dissatisfaction. There is a relationship between the package's ability to protect the product and consumers satisfaction according to their perception of product quality [1]. From the customers' point of view, packaging plays an important role during the buying process. Given that packaging is the first thing that consumers see before making the final decision of purchasing, its role in successful sale is indisputable.

When it comes to packaging color and labelling, previous studies have shown that each of these attributes can affect customers' perception of food and beverages. Furthermore, perception of flavour involves the combination of chemosensory information with both visual (color) information and cognitive, expectancy-based (label) inputs. Kim et al [2] investigated the effect of packaging labels and brand name on consumer liking and purchase intent of chocolate milk. Their results shown that organic labelling did not affect the purchase decision of chocolate milk, but positively influenced customer satisfaction. This finding is supported by existence of significant positive and predictive associations between brand loyalty and packaging, price and brand awareness [3]. It can be concluded that positioning strategy seems to be associated to some particular packaging elements. These elements are combined in different ways to transmit the desired perception in consumers' minds.

The choice of packaging materials depends on the properties of the material, economic viability, environmental protection and the packaging design in respect to the product. The most commonly used packaging materials are glass, plastic, cardboard, paper, metals, as well as 
composites [4]. Glass, as a package material, attracts consumers with their protective structure and transparency, whereas plastic and paperboard packages attract consumers with their resistance to physical impacts and easyto-use abilities [5].

Studies related to price have shown that customers tend to buy that brand of a product whose packaging is less likely to harm the environment [6]. On the other hand, some studies showed that the only positive influence on customers' perception was their past experience with the products, and this was not affected by the perception of the attributes such as green products, product labels, packaging materials and product ingredients [7].

The research which investigated the attitudes of Croatian consumer's demonstrated that perception of packaging choice can depend on the packaging materials. Furthermore, material preferences vary across different age groups. Older customers are less concerned with packaging materials, while younger customers show greater interest and greater knowledge of quality criteria and material safety [8]. However, when comparing with Swedish consumers, it seems that Swedish consumers are more aware of the lack in evaluation of the environmental aspects of food packaging [9].

In accordance with previously mentioned, it is evident that socio-demographic properties of consumers, price, product quality, package materials, package type, package attributes, labels and brands have high influence on the purchasing decision of food products.

In many cases, we can find same product packaged in different materials on store shelves. Research questions in this study are related to users' tendency for different packaging materials with respect to the same food product, the reasons for their choice according to packaging functionality, ecological awareness and choice of materials during first purchase and additional purchases of the same product.

The aim of this study is to evaluate user's tendencies when choosing a product that is offered in different packages. Independent variables are packaging materials in which the products are packaged, and the dependent variables are the users' choice of for the particular packaging material.

\section{Methodology}

A structured interview, with a pre-prepared reminder for the examiner, was used for the data collection. It contained topics and defined questions to be discussed with the respondents. With predefined determination of interviews, the conversation flow and relaxed communication with respondents succeed, making sure that each topic of the interview is included. The questions group within the interview included questions defined on the basis of the respondents' impression of the packaging material itself, the functionality of the packaging, its quality, durability and the tendency of the respondents toward the packaging material with respect to their personal attitudes (e.g. ecological awareness).

The questions were open type and allowed the participants the freedom to express themselves. A simple everyday language was used.

\subsection{Respondents}

The study included a group of 15 people ( $8 \mathrm{fe}$ male, 7 male; age range 35-59 years, mean age 47.6 years). All participants were employed and financially stable. Respondents were selected according to age and financial criteria. The research is carried out on a heterogeneous group with the aim of obtaining qualitied and detailed descriptions of respondents' individual attitudes about offered packaging materials.

\subsection{Samples}

Samples were products of the same net weight which were found on the market shelves in different packaging materials. The product category was food product whose structure is a dry substance. In order to make the research as precise as possible in the direction of the properties of the material from which the packaging is made, the price of the product was omitted as an influential and measurable factor.

Test samples were three types of consumer products that appear in the most commonly used packaging materials: glass, tin, plastic (low and high density polyethylene, poly(ethylene terephthalate, polypropylene) and composite flexible material (low density polyethylene/ aluminium). The products used were: instant coffee $(200 \mathrm{~g})$, cocoa drink powder (400 $\mathrm{g})$ and sugar powder (150 g). 
Figure 1. shows packaging samples for instant coffee (glass, tin, composite flexible material), Figure 2. shows packaging samples for cocoa drink powder - rigid and flexible plastics. Packaging samples for sugar powder are shown in Figure 3.: rigid and flexible plastics.

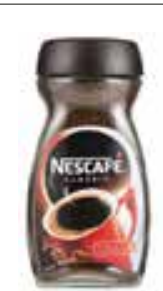

a)

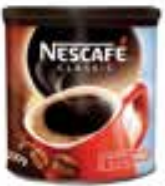

b)

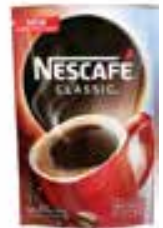

c)
Figure 1. Test samples for instant coffee a) glass b) tin c) composite flexible material

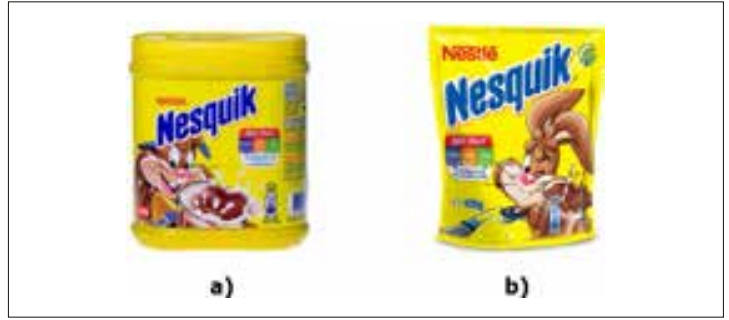

Figure 2. Test samples for cocoa drink powder a) rigid plastic b) flexible plastic

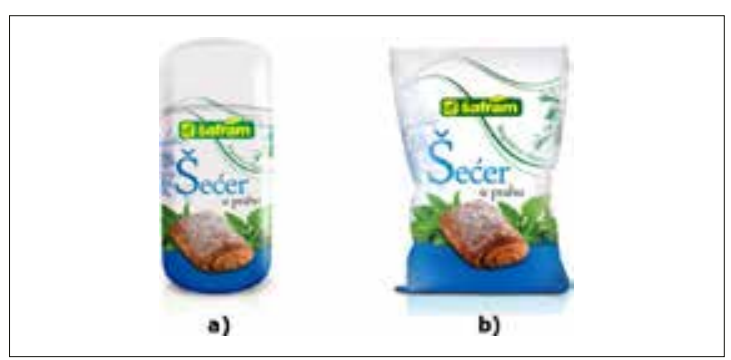

Figure 3. Test samples for sugar powder a) rigid plastic b) flexible plastic

Table 1. The choice of packaging material for coffee

\begin{tabular}{|c|c|c|c|c|c|}
\hline $\begin{array}{l}\text { Respondents } \\
\text { (age in years) }\end{array}$ & $\begin{array}{l}\text { Choice of } \\
\text { material } \\
\text { during first } \\
\text { purchase }\end{array}$ & $\begin{array}{l}\text { Explanation for the } \\
\text { choice of material } \\
\text { during first purchase }\end{array}$ & $\begin{array}{l}\text { Choice of material } \\
\text { during additional } \\
\text { purchase }\end{array}$ & $\begin{array}{l}\text { Explanation for } \\
\text { the choice of ma- } \\
\text { terial during addi- } \\
\text { tional purchase }\end{array}$ & $\begin{array}{l}\text { Respondent's } \\
\text { comments on non- } \\
\text { selected packaging } \\
\text { materials }\end{array}$ \\
\hline Female $1(56)$ & glass & natural material & $\begin{array}{l}\text { composite flexible } \\
\text { material }\end{array}$ & refilling glass jar & \\
\hline Male 1 (46) & glass & $\begin{array}{l}\text { transparency high } \\
\text { quality }\end{array}$ & glass & & \\
\hline Female 2 (56) & $\operatorname{tin}$ & $\begin{array}{l}\text { small weight } \\
\text { functionality }\end{array}$ & $\begin{array}{l}\text { composite flexible } \\
\text { material }\end{array}$ & refilling can & $\begin{array}{l}\text { disadvantage of glass } \\
\text { is fragileness }\end{array}$ \\
\hline Male 2 (47) & glass & $\begin{array}{l}\text { natural material } \\
\text { reusability }\end{array}$ & glass & & \\
\hline Male 3 (44) & $\operatorname{tin}$ & functionality & $\operatorname{tin}$ & & $\begin{array}{l}\text { disadvantage of glass } \\
\text { is fragileness }\end{array}$ \\
\hline Female 3 (59) & tin & $\begin{array}{l}\text { aesthetical } \\
\text { attractiveness }\end{array}$ & $\begin{array}{l}\text { composite flexible } \\
\text { material }\end{array}$ & refilling can & $\begin{array}{l}\text { disadvantage of glass } \\
\text { is heaviness }\end{array}$ \\
\hline Female 4 (35) & $\begin{array}{l}\text { composite } \\
\text { flexible } \\
\text { material } \\
\end{array}$ & small weight & $\begin{array}{l}\text { composite flexible } \\
\text { material }\end{array}$ & & \\
\hline Female 5 (39) & glass & $\begin{array}{l}\text { recyclability } \\
\text { reusability }\end{array}$ & $\begin{array}{l}\text { composite flexible } \\
\text { material }\end{array}$ & refilling glass jar & $\begin{array}{l}\text { disadvantage of tin is } \\
\text { low quality of material }\end{array}$ \\
\hline Male 5 (36) & glass & $\begin{array}{l}\text { aesthetical } \\
\text { attractiveness } \\
\text { reusability }\end{array}$ & glass & & $\begin{array}{l}\text { disadvantage of } \\
\text { composite flexible } \\
\text { material is non- } \\
\text { ecological waste }\end{array}$ \\
\hline Male 7 (45) & $\operatorname{tin}$ & $\begin{array}{l}\text { functionality } \\
\text { reusability }\end{array}$ & $\operatorname{tin}$ & & \\
\hline
\end{tabular}




\subsection{Procedure}

The interview was conducted over a period of 5 days. All questions were simple and unambiguous. The conversation was recorded and transcribed for better analysis. At the beginning, the packaging samples and the aim of the research were presented to the respondents. For each type of product they were asked to choose the packaging they would buy. The following questions related to:

- Knowledge of the properties of packaging materials and their impact on the environment

- Usability of packaging after consumption the content

- Convenience of packaging material for this type of product

Everyday products were used as test samples. Also, one of the aims was to find out whether people's choices of packaging material will differ during first purchase and additional purchases of the same product. At the end of the interview, respondents could add their comments or experiences regarding the selection of packaging products that were used as test samples.

\section{Results and discussion}

The results are presented by product type: coffee (Table 1), cocoa (Table 2) and sugar (Table 3). Each table shows the choice of packaging material and its explanation, as well as the respondents' comments on non-selected packaging materials. The comparison of the selection of packaging materials is shown in Figure 4.

Three coffee packaging materials were offered to respondents: glass, tin and composite flexible material. The results show that a large number of respondents (8) chose glass, while a smaller number of respondents (6) selected tin (Table 1). The composite flexible material was chosen by only one (youngest) respondent. The reason for glass selection is mostly reusability and recyclability. Several respondents said that, when purchasing the second time they would select a composite flexible material whose contents would then pour into the glass packaging. Respondents mentioned brittleness of the material as a major disadvantage of glass. Tin, as a packaging material, is primarily selected for convenience and low weight.

For cocoa as a product, respondents were able to choose between two packaging materials: rigid and flexible plastics. The results show

Table 2. The choice of packaging material for cocoa

\begin{tabular}{|l|l|l|l|}
\hline $\begin{array}{l}\text { Respondents } \\
\text { (age in years) }\end{array}$ & Choice of material & $\begin{array}{l}\text { Explanation for } \\
\text { the choice of } \\
\text { material }\end{array}$ & $\begin{array}{l}\text { Respondent's comments on non-selected packaging } \\
\text { materials }\end{array}$ \\
\hline Female 1 (56) & rigid plastic & functionality & disadvantage of flexible plastic is shedding \\
\hline Male 1 (46) & rigid plastic & functionality & disadvantage of flexible plastic is the lack of resealability \\
\hline Female 2 (56) & rigid plastic & functionality & $\begin{array}{l}\text { disadvantage of flexible plastic is weak protection of prod- } \\
\text { uct and shedding flexible plastic would be chosen only if } \\
\text { the product was on sale }\end{array}$ \\
\hline Male 2 (47) & rigid plastic & $\begin{array}{l}\text { functionality } \\
\text { reusability }\end{array}$ & \\
\hline Male 3 (44) & flexible plastic & $\begin{array}{l}\text { easy to throw in the } \\
\text { household waste }\end{array}$ & \\
\hline Male 4 (58) & rigid plastic & resealability & \\
\hline Female 3 (59) & rigid plastic & resealability & disadvantage of flexible plastic is shedding \\
\hline Female 4 (35) & flexible plastic & $\begin{array}{l}\text { easy to throw in the } \\
\text { household waste }\end{array}$ & advantage of rigid plastic is reusability \\
\hline Female 5 (39) & flexible plastic & recyclability & \\
\hline Male 5 (36) & rigid plastic & resealability & \\
\hline Female 6 (49) & rigid plastic & functionality & \\
\hline Female 7 (56) & rigid plastic & functionality & \\
\hline Female 8 (36) & flexible plastic & $\begin{array}{l}\text { easy to throw in the } \\
\text { household waste }\end{array}$ & \\
\hline Male 6 (52) & rigid plastic & easy to use & \\
\hline Male 7 (45) & rigid plastic & easy to use & \\
\hline
\end{tabular}


that the vast majority of respondents (11) selected rigid plastics, while a small number of respondents (4) selected flexible plastics (Table 2 ). The reason for rigid plastic selection was convenience, ease of use and re-closure, while the choice of flexible plastics was justified as the easiest waste disposal option. The main disadvantage of the flexible plastics is the inability to close which might result in product spilling.

In the case of sugar, there was also a choice between two packaging: rigid and flexible plastics. Since they are the same materials as for cocoa, almost the same results were obtained (Table 3 ). Rigid plastic was chosen by 10 respondents and flexible plastics of 5 . The reason for rigid plastic selection is also convenience and ease of use. It is interesting that two participants stated that the packaging material preference was solely because of habit. Similar results were obtained in the Sinclair study which showed that users prefer packaging material that they buy from habit [10].

The overview of selected packaging material in relation to the product type is shown in Figure 4. It can be seen that the choice of materials depends primarily on the functionality of the packaging in the meaning of re-use and convenience of use, and less of the product itself.

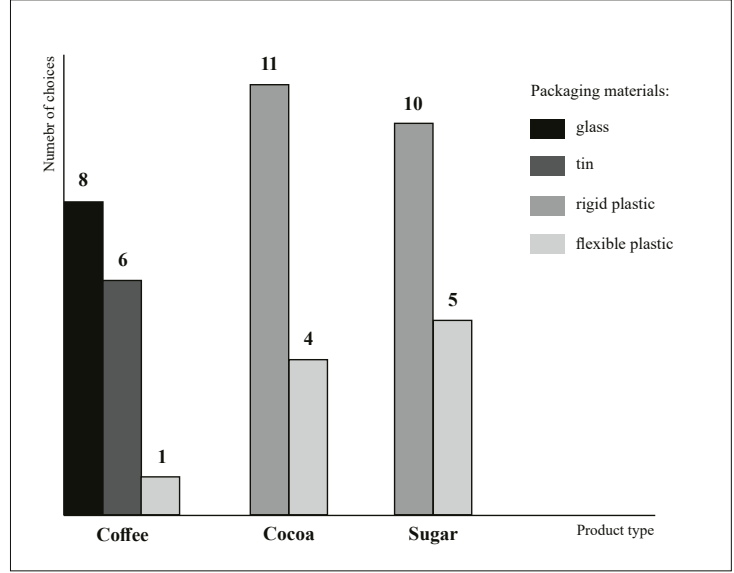

Figure 4. Choice of packaging materials for three products (coffee, cocoa and sugar)

Our experiment gathered data about respondents' attitudes toward packaging materials for three types of powder products: instant coffee, cocoa and sugar. The results showed that the age and gender of the respondents did not affect the preference of certain packaging material.

While looking the obtained results, it seems that buyers prefer to use more rigid packaging that can be reused and recycled. The first purchase of the product provides permanent packaging whose content is complemented by a later purchase of lightweight material. Similar findings were obtained by Klaiman et al [11] which presented that $34 \%$ of users emphasized

Table 3. The choice of packaging material for sugar

\begin{tabular}{|c|c|c|c|}
\hline $\begin{array}{l}\text { Respondents } \\
\text { (age in years) }\end{array}$ & $\begin{array}{l}\text { Choice of } \\
\text { material }\end{array}$ & $\begin{array}{l}\text { Explanation for the } \\
\text { choice of material }\end{array}$ & $\begin{array}{l}\text { Respondent's comments on non-selected packaging } \\
\text { materials }\end{array}$ \\
\hline Female $1(56)$ & rigid plastic & protection from shedding & product in flexible plastic is less expensive \\
\hline Male $1(46)$ & rigid plastic & functionality & $\begin{array}{l}\text { disadvantage of flexible plastic is the lack of resealabil- } \\
\text { ity }\end{array}$ \\
\hline Female $2(56)$ & rigid plastic & usefull for small amount & flexible plastic is useful for large amount \\
\hline Male $2(47)$ & rigid plastic & functionality & \\
\hline Male $3(44)$ & rigid plastic & functionality & \\
\hline Male 4 (58) & rigid plastic & $\begin{array}{l}\text { functionality } \\
\text { resealability }\end{array}$ & $\begin{array}{l}\text { disadvantages of flexible plastic is shedding and the } \\
\text { lack of resealability }\end{array}$ \\
\hline Female 3 (59) & flexible plastic & light weight of material & $\begin{array}{l}\text { disadvantages of rigid plastic is the heaviness of the } \\
\text { material }\end{array}$ \\
\hline Female 4 (35) & flexible plastic & habit & $\begin{array}{l}\text { advantage of the rigid plastic is steadfastness of the } \\
\text { material }\end{array}$ \\
\hline Female $5(39)$ & flexible plastic & flexibility of material & \\
\hline Male $5(36)$ & rigid plastic & $\begin{array}{l}\text { functionality } \\
\text { product protection }\end{array}$ & \\
\hline Female $6(49)$ & flexible plastic & habit & advantage of the rigid plastic is its functionality \\
\hline Female $7(56)$ & flexible plastic & functionality & advantage of the rigid plastic is fitting in storage space \\
\hline Female $8(36)$ & rigid plastic & functionality & \\
\hline Male 6 (52) & rigid plastic & easy to use & disadvantages of flexible plastic is shedding \\
\hline Male 7 (45) & rigid plastic & easy to use & \\
\hline
\end{tabular}


the usability of packaging and packaging material, while $31 \%$ of the users the greatest advantage ascribed to materials that are easily degradable and are not environmentally harmful. The tendency for a particular material is related to its characteristics in terms of packaging usability. Thus, in the case of instant coffee, most participants decided to choose glass as the strongest material, but at the second purchase, they chose a flexible plastic that serves as a disposable packaging. In the case of powdered products, the possibility of re-closing and opening was found to be very important for packaging. In addition, the participants stated that powder-based foodstuffs contained in packaging without the possibility of re-closure are susceptible to the penetration of harmful substances into the packaging and contaminating the product. It is therefore intended to protect the content with unimpaired reuse.

Arboretti and Bordignon [12] investigated the qualitative features of the packaging, such as reusability and the presence of lids, which proved to be extremely attractive when choosing a product and considering how to reuse it. Similar results were obtained in our study, where most of the participants chosen rigid plastic packaging for ease of use (dosage openings). Furthermore, Arboretti and Bordignon [12] demonstrated that the packaging material and the size/shape of the packaging play the most significant role in purchasing, especially when it comes to food packaging. This also confirmed by our results.

The ecological aspects of packaging material have shown a greater impact to the respondents in the case of a larger pool of materials (glass, tin, plastics and composite materials). On the other hand, when choosing between just two materials (rigid and flexible plastics), this aspect is neglected because of similar material characteristics and their environmental impacts, although one can argue that flexible packaging has a smaller impact on waste accumulation.

Recent research [11] have shown that a certain number of respondents prefer plastics when it comes to packaging materials with the highest reusability. The explanation was that plastics are more environmentally damaging than the other materials (glass and cardboard) because when deposited in landfills, they represent a bigger environmental damage, and that why it is the most important material for reuse.

\section{Conclusion}

The main role of packaging is product protection during storage, transport and use. Different packaging materials endeavour to ensure this function is at an adequate price. It is evident that the choice of packaging material to some extend depends on the product itself and the way it is used, but also on consumers' habits. The issue of packaging waste has recently started influencing buying decision when the same product on the store shelves is offered in different materials. Customers' awareness is changing and packaging is not only perceived as a consumable segment, but also as a tool for reusing the same or similar product. Our results demonstrated this very clearly. However, our study had some limitations. The experimental procedure did not reflect real shopping conditions, so conclusions about buying decisions cannot be generalized. Another limitation is that we were focused on just one type of food product (i.e. powders). Liquids, creams and hard food are common categories which were all excluded from our study. Future research should be directed to this aim, which will seek to gain a more detailed insight into consumer preferences towards marketable packaging.

\section{References:}

1 Abdalkrim, G.M., AL-Hrezat, R.S., 2013. The Role of Packaging in Consumer's Perception of Product Quality at the Points of Purchase. European Journal of Business and Management, 5(4), pp. 69-82

2 Kim, M. K., Lopetcharat, K., Drake, M.A., 2013. Influence of packaging information on consumer liking of chocolate milk. Journal of Dairy Science, 96(8), pp. 4843-4856

3 Dhurup, M., Mafini, C., Dumasi, T., 2014. The impact of packaging, price and brand awareness on brand loyalty: Evidence from the paint retailing industry. Acta Commercii, 14(1), pp. 1-9

4 Marsh, K., Bugusu, B., 2007. Food Packaging - Roles, Materials and Environmental Issues. Journal of Food Science, 72(3), pp. 39-55

5 Aday, M., Yener, U., 2014. Understanding the buying behaviour of young consumers regarding packaging attributes and labels. International Journal of Consumer Studies, 38(4), pp. 385-393

6 Baker, M. J., 1991. Marketing: An Introductory Text 5th ed. Basingstoke: Macmillan Education 
7 D’Souza, C., Taghian, M., Lamb, P., Peretiatkos, R., 2006. Green Products and Corporate Strategy: an Empirical Investigation. Society and Business Review, 1(2), pp. 144- 157

8 Drašković, N., Temperley, J., Pavičić, J., 2009. Comparative Perception(s) of Consumer Goods Packaging: Croatian Consumers' Perspective. International journal of management cases, 11(2), pp. 154-163

9 Lindh, H., Olsson, A., Williams, H., 2016. Consumer Perceptions of Food Packaging: Contributing to or Counteracting Environmentally Sustainable Development? Packaging Technology and Science, 29, pp. 3-23

10 Sinclair, J., 2007. A comparison of material preferences by chocolatiers and consumers. Thesis. Rochester Institute of Technology. Available from: http://scholarworks.rit.edu/theses/366 [accessed 15 May 2016]

11 Klaiman, K., Ortega, D.L., Garnache, C., 2016. Consumer preferences and demand for packaging material and recyclability. Resources, Conservation and Recycling, 115, pp. 1-8

12 Arboretti, R., Bordignon, P., 2016. Consumer preferences in food packaging: CUB models and conjoint analysis. British Food Journal, 118(3), pp. 527-540 
This page was left blank intentionally! 